TITLE:

\title{
Gender Identification by Calls and Body Size of the Streaked Shearwater Examined by CHD Genes
}

\section{$\operatorname{AUTHOR}(\mathrm{S})$ :}

Arima, Hiroshi; Oka, Nariko; Baba, Yoshiyuki; Sugawa, Hisashi; Ota, Takahiro

\section{CITATION:}

Arima, Hiroshi ...[et al]. Gender Identification by Calls and Body Size of the Streaked Shearwater Examined by CHD Genes. Ornithological Science 2014, 13(1): 9-17

\section{ISSUE DATE:}

2014-06

URL:

http://hdl.handle.net/2433/199662

\section{RIGHT:}

(c) 2014 The Ornithological Society of Japan; 許諾条件により本文ファ イルは2016-07-01に公開. 


\title{
Gender Identification by Calls and Body Size of the Streaked Shearwater Examined by CHD Genes
}

\author{
Author(s): Hiroshi Arima, Nariko Oka, Yoshiyuki Baba, Hisashi Sugawa and Takahiro Ota
}

Source: Ornithological Science, 13(1):9-17.

Published By: The Ornithological Society of Japan

DOI: http://dx.doi.org/10.2326/osj.13.9

URL: http://www.bioone.org/doi/full/10.2326/osj.13.9

BioOne (www.bioone.org) is a nonprofit, online aggregation of core research in the biological, ecological, and environmental sciences. BioOne provides a sustainable online platform for over 170 journals and books published by nonprofit societies, associations, museums, institutions, and presses.

Your use of this PDF, the BioOne Web site, and all posted and associated content indicates your acceptance of BioOne's Terms of Use, available at www.bioone.org/page/terms_of_use.

Usage of BioOne content is strictly limited to personal, educational, and non-commercial use. Commercial inquiries or rights and permissions requests should be directed to the individual publisher as copyright holder. 


\title{
Gender identification by calls and body size of the Streaked Shearwater examined by CHD genes
}

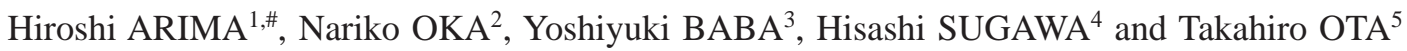 \\ ${ }^{1}$ Faculty of Medicine, Kyoto University, Yoshida-Konoe cho, Sakyo ku, Kyoto 606-8501, Japan \\ ${ }^{2}$ The Yamashina Institute for Ornithology, 115 Konoyama, Abiko, Chiba 270-1145, Japan \\ ${ }^{3}$ Kyushu University, 4-2-1 Ropponmatsu, Fukuoka 810-0044, Japan \\ ${ }^{4}$ Fukakusa Campus, Ryukoku University, 67 Fukakusa-Tsukamoto, Fushimi ku, Kyoto 612-8577, Japan \\ ${ }^{5}$ Faculty of Agriculture, Kyoto University, Kitashirakawa-Oiwake cho, Sakyo ku, Kyoto 606-8502, Japan
}

\section{ORNITHOLOGICAL SCIENCE \\ (C) The Ornithological Society of Japan 2014}

\begin{abstract}
Like most seabirds Streaked Shearwaters Calonectris leucomelas have sexually monomorphic plumage. Researchers have conveniently identified gender in the field by means of two types of calls, associated with dimorphism in body size. By molecular sexing analysis using the chromo-helicase-DNA-binding (CHD) genes, we determined the gender of Streaked Shearwaters in relation to call types and body size. We recorded the type of calls, measured body dimensions and collected non-invasive samples (buccal cells or feathers) of Streaked Shearwaters at two breeding islands. As obvious amplification to identify gender by polymerase chain reaction (PCR) could not be obtained at high rates using a known universal primer pair, we developed two new primer pairs to identify gender in this species; this enabled us to identify the gender of all of the samples. Without exception all males gave high-pitched calls, whereas all females gave low-pitched calls. Molecular evidence also confirmed morphometric differences between males and females. We, therefore, conclude that Streaked Shearwaters exhibit sexual dimorphism in body size and call type. Males are significantly larger than females, and males give high calls whereas females give low calls.
\end{abstract}

Key words Call type, Chromo-helicase-DNA-binding (CHD) genes, Sexual dimorphism, Streaked Shearwater Calonectris leucomelas
Identification of the sex of birds is fundamentally essential for various studies including: ecology, evolutionary biology, ethology, and conservation biology related to gender. Many terrestrial birds have evolved external appearance, such as plumage color or shape, that different by sex, while most seabird species appear sexually monomorphic (Welty \& Gaptista 1988). Therefore, the development of methods to identify the sex of each seabird species based on sexual characteristics other than visual appearance is essential especially in the field.

The Streaked Shearwater Calonectris leucomelas, Aves Procellariidae, is typical of such seabirds in that neither plumage color nor shape facilitate identification of sex (Brooke 2004). They breed at high densities on islands and islets along the Japanese Archi-

(Received 12 July 2012; Accepted 19 November 2013)

\# Corresponding author, E-mail: hiarima@kuhp.kyoto-u.ac.jp pelago in the westernmost North Pacific, East China Sea and the Sea of Japan (Oka 2004). Throughout their breeding season from their arrival at their colony in March to their departure from their colony in November, they are nocturnal, returning to their colonies from the sea after sunset, and often calling loudly as they land and while on the ground (Yoshida 1962; Jida et al. 1987; Oka et al. 2002; Yamamoto et al. 2011; Yamamoto et al. 2012). Among nocturnal petrels, vocalization seems to play an important role in intraspecific communication (Brooke 1986; Warham 1996; Cure et al. 2009), and it has long been suggested that male and female Streaked Shearwaters have different calls (Kuroda 1956; Kiyosu 1965; Sugawa \& Arima 2002). In the congeneric Cory's Shearwater Calonectris diomedea, Ristow and Wink (1980) and Bretagnolle and Lequette (1990) distinguished two types of calls, and associated the highpitched calls with males and the low-pitched calls 
H. ARIMA et al.

with females. In the Streaked Shearwater, two similar types of calls have been identified (Arima \& Sugawa 2004): high-pitched (the high call) and low-pitched calls (the low call); and these calls were associated with different body sizes indicating that the two types of calls might relate to gender. Though molecular evidence to identify gender has been lacking, researchers in the field have conveniently used the two types of calls for gender discrimination in study protocols (see Takahashi et al. 2008; Ochi et al. 2010; Yamamoto et al. 2011). As the nocturnal seabirds exhibit high vocal activity, underlining the usefulness of acoustic cues in their breeding systems, gender discrimination by call has the potential for being a key protocol for biological, ecological, and physiological studies, not only for vocal communication, but also for gender effects to allocate investments in parental attentiveness. Chicks similarly grow to fledge to make two types of calls, which differ from the high-pitched begging calls of younger chicks to their parents (Oka unpublished). This may promote the study of the gender effect on chick growth and development. The identification of sexual differences in calls will also allow the detection of gender effects on partnerships, parental attentiveness, and growth and development of chicks.

In this study, we examined the differences between the calls and body dimensions of male and female Streaked Shearwaters, using a molecular sexing method based on avian chromo-helicase-DNA-binding (CHD) genes (see Griffith \& Korn 1997; Griffiths et al. 1998; Kahn et al. 1998; Fridolfsson \& Ellegren 1999; Dubiec \& Zagalska-Neubauer 2006; Cerit \& Avanus 2007; Reis et al. 2011). This is the first paper to identify gender of the Streaked Shearwater using a molecular sexing method in relation to sexual dimorphism in calls and body dimensions.

\section{MATERIALS AND METHODS}

\section{1) Study sites and sampling}

We conducted fieldwork on two breeding islands of the Streaked Shearwater; Kanmuri Island in the southernmost Sea of Japan $\left(35^{\circ} 40^{\prime} \mathrm{N}, 135^{\circ} 25^{\prime} \mathrm{E}\right.$, Maizuru, Kyoto Prefecture) and Mikura Island in the western North Pacific $\left(33^{\circ} 52^{\prime} \mathrm{N}, 139^{\circ} 36^{\prime} \mathrm{E}\right.$, Izu Islands, Tokyo), under permits from local government and from the Ministry of Environment of Japan, during the breeding season in 2004. We conducted fieldwork in May (mating season) on Kanmuri Island (Yoshida 1962); and in August and September (the first half of their chick-rearing season) on Mikura Island (Oka et al. 2002).

We captured adult birds on the ground or in burrows by hand and collected non-invasive samples (buccal cells or feathers) for the DNA analyses. On Kanmuri Is., we collected buccal cells by rolling a cotton swab in the mouth and throat of each bird for ca. five seconds, and placed the swab into a microtube containing $1 \mathrm{ml}$ of $99.5 \%$ ethanol, and rotated it for ca. $10 \mathrm{~s}$. We repeated this procedure once more using another swab and put the swab into the same micro-tube, and kept the micro-tube at $-20^{\circ} \mathrm{C}$ in the laboratory for three months until analysis. On Mikura Is., we plucked a few small feathers from each bird and kept them in an envelope in a dry box with desiccant and then stored them in a freezer until analysis.

We identified the type of calls (high or low; see Fig. 1 for reference) for each bird that called during handling, as many birds made calls when collecting samples. The calls were transcribed as "Pi- $\cdot \mathrm{uWi}$ $\mathrm{a} \cdot \mathrm{a}$ " (the high call) and "Ga- - gua-" (the low call), like those reported by Kuroda (1954), Kiyosu (1965) and Arima \& Sugawa (2004). As the dominant frequency of the two call types differed vastly from each other (about $13 \mathrm{kHz}$ for the high call and about $5 \mathrm{kHz}$ for the low call), as shown in the sonogram (Fig. 1), we were able to identify the two call types even when they produced only a short call.
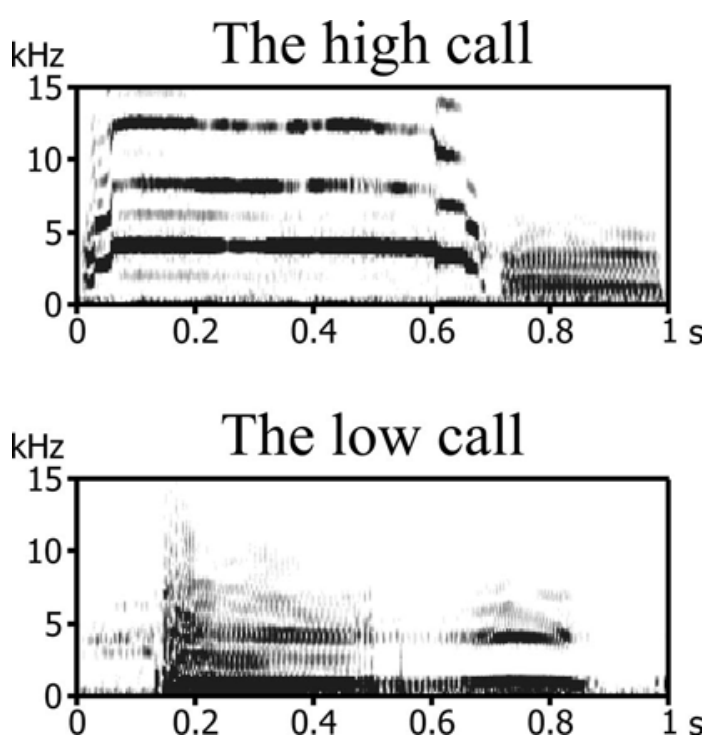

Fig. 1. Sonograms of the typical phrases of the two major types of vocalization given by Streaked Shearwaters: a highpitched call (the high call) and a low-pitched call (the low call) (Adapted from Arima \& Sugawa 2004). 
Sexual dimorphism of the calls of Streaked Shearwater examined by CHD genes
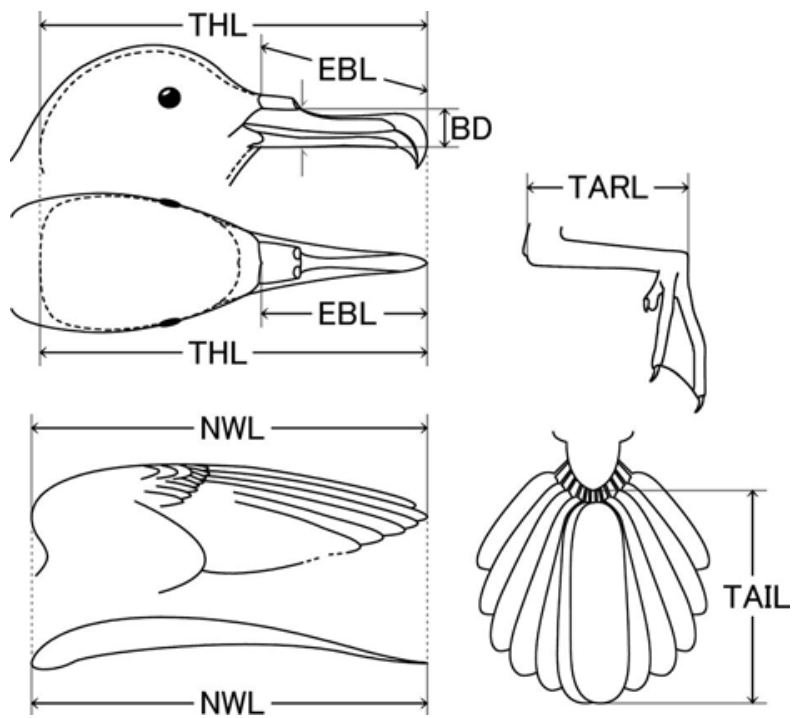

Fig. 2. Morphometric measurements taken in this study. (NWL, natural wing length; TAIL, tail length; TARL, tarsus length; THL, total head length; EBL, exposed culmen length; $\mathrm{BD}$, bill depth at anterior edge of nostril).

We measured the dimensions of each bird at the two islands to within $0.1 \mathrm{~mm}$ by caliper and to within $1 \mathrm{~mm}$ by ruler, and banded them for individual identification so as not to collect data from the same bird twice. Birds were released immediately after data collection at the study sites. The dimensions measured were: total head length, exposed culmen, tarsus, wing, tail, and bill depth at the anterior edge of the nostril (Fig. 2).

We collected non-invasive samples and measured the body dimensions of 69 birds in total, consisting of 31 birds on Kanmuri Is. and 38 on Mikura Is. Among them, we could identify the call type for 63 birds, consisting of 31 (16 giving high calls and 15 giving low calls) on Kanmuri Is. and 32 (16 giving high calls and 16 giving low calls) on Mikura Is.

\section{2) DNA extraction and purification}

Each buccal cell sample was digested overnight in $400 \mu \mathrm{l}$ of STE buffer $(150 \mathrm{mM} \mathrm{NaCl} ; 10 \mathrm{mM}$ Tris-HCl, pH 8.0; $10 \mathrm{mM}$ EDTA) with $4 \mu \mathrm{l}$ of $10 \%$ Sodium dodecyl sulfate (SDS) and $80 \mu \mathrm{g}$ proteinase $\mathrm{K}$ at $37^{\circ} \mathrm{C}$. Either a whole feather or the root of a feather was sliced into small fragments (Baba et al. 2001). Then, DNA was purified by the conventional phenol/chloroform method (Maniatis et al. 1982) or with an IsoQuick kit (ORCA Research Inc., Bothell, Wash.).
3) Design of new primer pairs for specific amplification of the Streaked Shearwater CHD genes

We performed a preliminary examination to identify the gender of buccal cells from 31 Streaked Shearwaters, using the molecular sexing method based on a universal primer pair $2550 \mathrm{~F} / 2718 \mathrm{R}$ (Fridolfsson \& Ellegren 1999) that had been examined and found effective to amplify avian CHD genes for a number of non-ratite bird groups (Fridolfsson \& Ellegren 1999), following the same molecular methods for the buccal cells described in Arima \& Ohnishi (2006). The gender of each bird was identified if obvious amplification of expected length representing $C H D-W$ (between 400 and $450 \mathrm{bp}$ in size) and/or CHD-Z (between 600 and $650 \mathrm{bp)}$ genes was obtained by polymerase chain reaction (PCR) (see Fridolfsson \& Ellegren 1999, and Arima \& Ohnishi 2006). However, as obvious amplification to identify gender could not be obtained by PCR at high rates using the previously known universal primer pair (see RESULTS), we designed two new primer pairs which specifically amplify the Streaked Shearwater $C H D-W$ and $C H D-Z$ genes, as described below.

First, a region including intron 9 of the Streaked Shearwater CHD genes was amplified by PCR using a primer pair 1237L/1272H (Kahn et al. 1998) from four genomic DNA samples. Those DNA samples were from buccal cells of two males and two females randomly selected from 22 birds whose genders were identified by the universal primer pair $2550 \mathrm{~F} / 2718 \mathrm{R}$ as described above (see also RESULTS: Molecular sexing with the universal primer pair $2550 \mathrm{~F} / 2718 \mathrm{R}$ ). Each PCR was carried out in $12.5 \mu \mathrm{l}$ volumes containing $10 \mathrm{mM}$ Tris- $\mathrm{HCl}(\mathrm{pH} 8.3), 50 \mathrm{mM} \mathrm{KCl}, 1.5$ $\mathrm{mM} \mathrm{MgCl} 2,0.2 \mathrm{mM}$ of an equimolar solution of dNTPs, $2.5 \mu \mathrm{g}$ of bovine serum albumin (BSA), 0.4 units of Ex Taq DNA polymerase (Takara), and 2 pM of each primer. Each PCR mixture contained genomic DNA of each bird as a template. The thermal profile comprised an initial denaturing step at $94^{\circ} \mathrm{C}$ for 2 min followed by 30 cycles of denaturing at $94^{\circ} \mathrm{C}$ for $30 \mathrm{~s}$, annealing at $55^{\circ} \mathrm{C}$ for $30 \mathrm{~s}$, and extension at $72^{\circ} \mathrm{C}$ for $60 \mathrm{~s}$. A final extension step of $72^{\circ} \mathrm{C}$ for $5 \mathrm{~min}$ was added after the last cycle. Each amplified fragment was cloned into the plasmid vector pCR2.1 (TOPO TA Cloning kit, Invitrogen, California), and was sequenced using the T7 promoter primer (GTAATACGACTCACTATAGGGC) and ABI 3130XL genetic analyzer (Applied Biosystems, Foster City, CA). The sequences were aligned with the chicken $C H D-W$ (GenBank accession No. 
H. ARIMA et al.

AF181826, Fridolfsson \& Ellegren 1999) and CHD-Z (GenBank accession No. AF004397, Griffiths \& Korn 1997) genes using BioEdit version 7.2.0 software (Hall 1999, http://www.mbio.ncsu.edu/bioedit/ bioedit.html), and partial sequences of the Streaked Shearwater $C H D-W$ and $C H D-Z$ genes were identified by homology with their chicken counterparts. The percentages of common identity between aligned sequences were calculated with the identity matrix module of BioEdit.

Then, sequences of the Streaked Shearwater $C H D-W$ and $C H D-Z$ genes were aligned with each other, and we designed two new primer pairs for specific amplification of the Streaked Shearwater $C H D-W$ and $C H D-Z$ genes, based on the discrepancy between intron sequences of these genes: primer pair $1238 \mathrm{~F}$ (5'-AAACAGGGGTTTTGACCAACTAAC-3') and W1R (5'- AATTTCAGATTAAGTAGTTCAAAGCTATGTG-3') for the Streaked Shearwater $C H D-W$ gene, and primer pair $\mathrm{Z} 1 \mathrm{~F}$ (5'-GTGTCTTTTCGTTCTGACTGACTTG-3') and Z1R (5 '-CGCCTCCCTTCACTTCCATTAAAGC-3') for the Streaked Shearwater $C H D-Z$ gene. These primers were checked and simulated with pDRAW32 Ver. 1.0 (ACACLONE software, http://www.acaclone. com/) and FastPCR (Kalendar et al. 2011).

\section{4) Molecular sexing based on the Streaked Shear- water CHD genes}

Two PCR analyses were performed for each bird to identify its gender; one with the primer pair $1238 \mathrm{~F}$ and W1R (for $C H D-W$ gene), and the other with the primer pair Z1F and Z1R (for $C H D-Z$ gene). The thermal profile comprised an initial denaturing step at $94^{\circ} \mathrm{C}$ for 3 min followed by 30 cycles of denaturing at $94^{\circ} \mathrm{C}$ for $30 \mathrm{~s}$, annealing at $55^{\circ} \mathrm{C}$ for $30 \mathrm{~s}$, and extension at $72^{\circ} \mathrm{C}$ for $60 \mathrm{~s}$. A final extension step of $72^{\circ} \mathrm{C}$ for 5 min was added after the last cycle. The makeup of reaction mixtures was identical to those above. PCR products were resolved by $1.5 \%$ agarose gel electrophoresis applied with High Ranger Plus 100 bp DNA Ladder (Norgen, Canada), and the DNA fragments were visualized by UV light trans-illumination and ethidium bromide staining. Male birds were identified when the PCR for $C H D-Z$ gene produced amplification of expected length (see RESULTS) but that for $C H D-W$ gene did not. Female birds were identified when both PCRs for $C H D-W$ and $C H D-Z$ genes produced amplification of expected length (see RESULTS).

When neither of the PCRs for $C H D-W$ and $C H D-Z$ genes produced amplification, we performed two-step PCRs as follows. First PCR was performed using primer pair 1237L/1272H (Kahn et al. 1998) and the genomic DNA of each bird as a template. Second PCR for $C H D-W$ gene was performed using primer pair $1238 \mathrm{~F} / \mathrm{W} 1 \mathrm{R}$ and $5 \%$ of the first PCR product as a template, and second PCR for CHD-Z gene was performed using primer pair $Z 1 F / Z 1 R$ and $5 \%$ of the first PCR product as a template. The thermal profile and makeup of reaction mixtures were identical to those described above.

Gender identification by PCR analyses with the primer sets developed in this study was performed for 22 birds whose genders were identified by the universal primer pair $2550 \mathrm{~F} / 2718 \mathrm{R}$ (see RESULTS: Molecular sexing with the universal primer pair $2550 \mathrm{~F} / 2718 \mathrm{R}$ ) to check whether genders identified by primer sets developed in this study were consistent with genders identified by the universal primer pair $2550 \mathrm{~F} / 2718 \mathrm{R}$. Then, genders of all birds were identified by PCR analyses with the primer sets developed in this study.

\section{5) Statistical analysis}

As we studied measurements of birds from two islands, we analysed measurements focusing on the effects of population as well as those of gender. Among the 69 study birds we lacked several measurements of nine birds from Kanmuri Island. Therefore we analysed, by multivariate analysis of variance (MANOVA), the effects of gender and population and the interaction between them on: body dimensions (total head length, exposed culmen length, bill depth at anterior edge of nostril, natural wing length, tail length, and tarsus length), using measurements taken from the remaining 60 birds ( 22 from Kanmuri Is. and 38 from Mikura Is.). After MANOVA, we assessed which variables were responsible for the significant main effects by a univariate analysis of variance (two-way ANOVA) of each response variable. Both were tested using JMP software package (http://www.jmp.com/). The level of significance of all statistical analyses was $P<0.05$. Measurements were given as means $\pm \mathrm{SE}$.

\section{RESULTS}

\section{1) Nucleotide sequences of the Streaked Shear- water $\mathrm{CHD}$ gene}

A total of $228 \mathrm{bp}$ of a region including intron 9 of the Streaked Shearwater $C H D-W$ and $C H D-Z$ genes 
Sexual dimorphism of the calls of Streaked Shearwater examined by CHD genes

were determined from four genomic DNA samples. Both the Streaked Shearwater $C H D-W$ and $C H D-Z$ sequences were constructed with 34 bp of exon (Kahn et al. 1998) and 194 bp of intron. The calculated percentage of common identity between intron sequences of the Streaked Shearwater CHD-W and the chicken $C H D-W$ genes was 0.531 , and that between the Streaked Shearwater $C H D-Z$ and the chicken $C H D-Z$ genes was 0.562 . The calculated percentage of common identity between intron sequences of the Streaked Shearwater CHD- $W$ and CHD Z genes was 0.684 . Sequence data of the Streaked Shearwater $C H D-W$ and $C H D-Z$ genes have been submitted to the GenBank database under accession numbers AB279887 and AB279888, respectively.

\section{2) Molecular sexing with the universal primer pair $2550 \mathrm{~F} / 2718 \mathrm{R}$}

No obvious amplification to identify gender was obtained by single PCRs using the known universal primer pair $2550 \mathrm{~F} / 2718 \mathrm{R}$ for all of the examined 31 DNA samples purified from buccal cells. Second PCRs using $5 \%$ of the single PCR product as a template (two-step PCR; see Arima \& Ohnishi 2006) yielded obvious amplification of expected length representing $C H D-W$ (between 400 and $450 \mathrm{bp}$ in size) and/or $C H D-Z$ (between 600 and $650 \mathrm{bp}$ ) genes for $22(71.0 \%)$ out of the 31 birds examined, which enabled us to identify their genders (11 males and 11 females). In the remaining nine birds, however, obvious amplification could not be obtained by the universal primer pair, even after the second PCRs.

\section{3) Molecular sexing with the primer sets developed in this study}

Two primer sets developed in this study, one set for the Streaked Shearwater $C H D-W$ gene and the other for the Streaked Shearwater $C H D-Z$ gene, amplified $196 \mathrm{bp}$ and 223 bp fragments, respectively (Fig. 3). Genders identified by PCR analyses with the primer sets developed in this study was perfectly consistent with gender identification by the universal primer pair $2550 \mathrm{~F} / 2718 \mathrm{R}$ for all of the 22 birds examined. Then, genders of a total of 69 birds were identified by PCR analyses with the primer sets developed in this study. Among the 63 birds we examined for which gender was also associated with call type, 32 were identified as males and 31 as females. Among them, the gender of 35 birds ( 19 males and 16 females) was identified by single PCR, and that of the remaining 28 birds (13 males and 15 females) was identified by

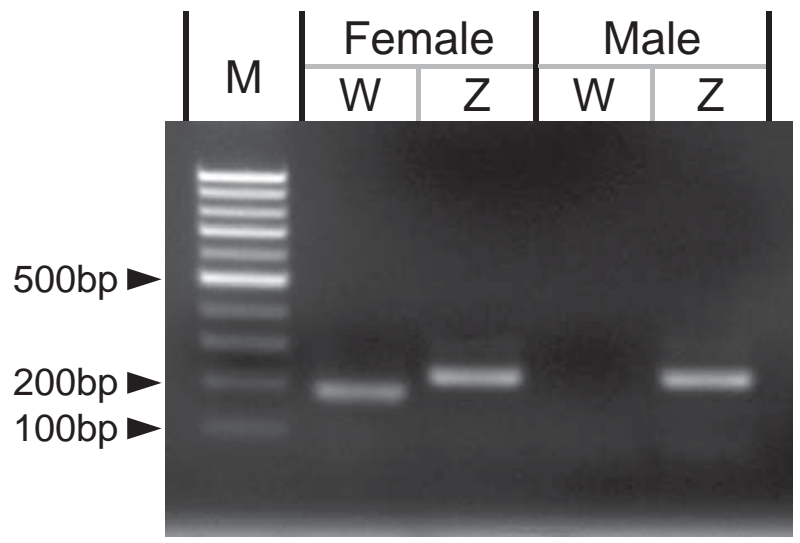

Fig. 3. Gender identification of Streaked Shearwaters examined by CHD genes. A 196 bp fragment was amplified from the Streaked Shearwater $C H D-W$ gene by PCR with a primer pair $1238 \mathrm{~F} / \mathrm{W} 1 \mathrm{R}$, and a $223 \mathrm{bp}$ fragment was amplified from the Streaked Shearwater $C H D-Z$ gene by PCR using a primer pair Z1F/Z1R. The lane marked "M" contains High Ranger Plus 100 bp DNA Ladder (Norgen, Canada).

two-step PCR. Measurements of 60 birds (30 males and 30 females) were analysed, as several measurements of nine birds from Kanmuri Is. were lacking. There were no cases involving any inhibition of PCR amplification, even after two-step PCR or extra amplification, as can be caused by contamination, so severe as to make sex identification impossible with either buccal cell or plumage samples.

\section{4) Sexual dimorphism in calls}

Among the 63 birds we examined for gender associated with call types, all 32 of the birds that gave high calls were confirmed to be males, and all 31 of the birds that gave low calls were confirmed to be females (Table 1). The high and low calls differ so obviously from each other (Fig. 1) that they can be distinguished easily and reliably in the field.

\section{5) Gender and population dimorphism in body dimensions}

There were significant multivariate effects associated with both gender and population on body dimensions, but there was no significant interaction between gender and population (Table 2). Subsequent ANOVAs showed that gender and population significantly affected all measurements with the exception of tail length (Table 3), although the interaction between gender and population had no effect on any of these variables (Table 2). In summary, overall, males were significantly larger than females in five 
H. ARIMA et al.

Table 1. Agreements of 63 Streaked Shearwaters between call type and gender determined by CHD genes.

\begin{tabular}{lccc}
\hline Call type & a) Number of birds & $\begin{array}{l}\text { b) Results of gender determination by } \\
\text { molecular method based on CHD genes }\end{array}$ & Agreement in \% (b/a) \\
\hline High call & 32 & All males & $100(32 / 32)$ \\
Low call & 31 & All females & $100(31 / 31)$ \\
\hline
\end{tabular}

Table 2. The results of MANOVA of six morphological characters of Streaked Shearwaters to test the effects of gender and population.

\begin{tabular}{lccccc}
\hline \multicolumn{1}{c}{ Factors } & Wilks' $\wedge$ & $\begin{array}{c}\text { Approxmated } \\
\text { or exact F }\end{array}$ & df & P \\
\hline Whole & 0.2649 & 5.9297 & $15,143.95$ & $<0.0001$ \\
Gender & - & 7.3089 & 5,52 & $<0.0001$ \\
Population & - & 10.9844 & 5,52 & $<0.0001$ \\
Gender*Population & - & 1.233 & 5,52 & 0.3071 \\
\hline
\end{tabular}

body size variables (total head length, exposed culmen length, bill depth at anterior edge of nostril, natural wing length, and tarsus length) but not in tail length. More specifically the Kanmuri Island population was significantly larger than the Mikura Island population in five body size variables (total head length, exposed culmen length, bill depth at anterior edge of nostril, natural wing length, and tail length), but with slightly shorter tarsi (Table 3 ).

\section{DISCUSSION}

In this study, obvious amplification to identify gender by PCR using the previously known universal primer pair $2550 \mathrm{~F} / 2718 \mathrm{R}$ could not be obtained at a satisfactory rate with DNA from buccal cells. Although buccal cells have previously been used successfully for non-invasive genetic analysis in birds, lower yields of DNA from buccal cells than from blood samples and potential contamination of buccal cell samples by PCR inhibitors (which may be contained in residue inside the oral cavity) have been reported (Seki 2003; Arima \& Ohnishi 2006). Therefore, we infer that these potential defects of the noninvasive samples may have caused the unsatisfactory success rate of PCR using a universal primer pair in this study. On the one hand, considering that the genders of all of the DNA samples tested, including those from buccal cells, could be successfully identified by using the newly developed primer pairs in this study, the two new primer pairs should surpass the universal primer pair for gender identification of the Streaked
Shearwater from non-invasive DNA samples with low yields of DNA, such as those from buccal cells. On the other hand, considering that Genovart et al. (2005) successfully used the previously described primer pair $2550 \mathrm{~F} / 2718 \mathrm{R}$ to determine the gender of the congeneric Cory's Shearwater $C$. diomedea diomedea, the previously known primers may work properly in the Streaked Shearwater too, if adequate amounts of purified DNA, such as those from blood, are tested.

Gender dimorphism in the calls of the Streaked Shearwater was clearly shown and unequivocal; adult males give high calls and adult females give low calls. This gender dimorphism in vocalizations, in which males produce higher pitched calls than females, is common among nocturnal petrels and has been reported for other shearwater species too, such as Manx Shearwater Puffinus puffinus (Brooke 1978), Yelkouan Shearwater P. yelkouan and Cory's Shearwater (Cure et al. 2009). Those shearwaters also exhibit gender dimorphism in body size, as does the Streaked Shearwater, wherein males are larger than females. These characteristics seem to contradict the general biological rule in numerous avian species that lower pitched calls are associated with larger size, as calls are suspected of reflecting body size or mass (Wallschläger 1980; Fletcher 2004). As for the Streaked Shearwater, males return to their breeding islands at night more frequently than do females during the pre-laying period (Yamamoto et al. 2011) and vocalize loudly, possibly for mate recognition, to attract potential mates, and also for territorial defense 
Sexual dimorphism of the calls of Streaked Shearwater examined by CHD genes

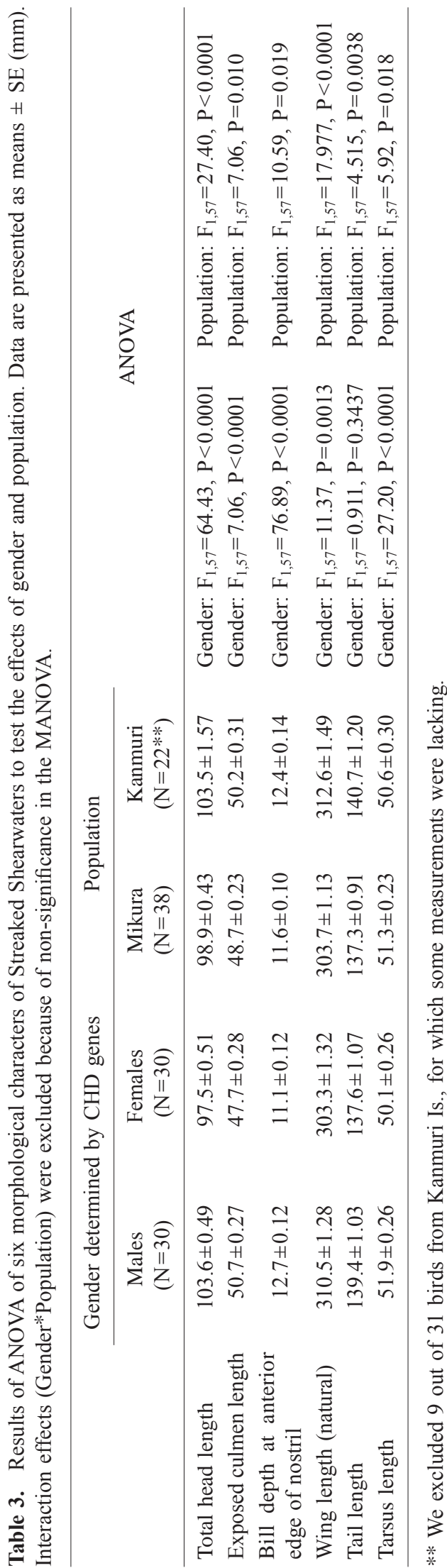

and competition for mates, as is the case in other nocturnal shearwaters (McNeil et al. 1993; Warham 1996; Cure et al. 2009). To our knowledge, with the exception of Cure et al. (2009) there have been few studies of vocalizations in nocturnal petrels in relation to intraspecific behavior and habitat-dependent environmental sounds. The breeding islands of the Streaked Shearwater are typically densely covered with warm-temperate evergreen forest (Jida et al. 1987; Maesako 1991) with a sound environment that includes wind, waves and the rustling of leaves. Male Streaked Shearwaters may have evolved higher pitched calls under such environmental selection pressures to overcome the ambient sound at their colonies, as the further their calls carry, and the clearer their acoustic signals are in the dark, the more effective they should be in mate recognition, attraction of potential mates, territorial defense, and in competition for mates.

As shearwaters become silent at their colonies as the breeding season progresses, calls may prove to be an uncertain method for gender identification during certain periods of the breeding season. Then, instead of vocalizations, body size may prove to be more useful criteria for discriminating gender. However, we found that morphometric dimorphism occurs not only between genders, but also between populations (between populations breed at similar latitudes, but in different oceans separated by Honshu, an island approximately $1,800 \mathrm{~km}$ in length). This may indicate the existence of geographical morphological variation in the Streaked Shearwater, as has been shown for the Short-tailed Shearwater Puffinus tenuirostris (Carey 2011). If so, a discriminant model for sex identification developed from measurements of just one colony may not correctly discriminate between the sexes of birds from other colonies. Our sample size, a few tens individuals, may be too small to prove the potential geographical variations in morphology between populations. Further biometric studies are essential to understand the degree of conspecific geographical variation in body size of the Streaked Shearwater.

\section{ACKNOWLEDGMENTS}

We are grateful to the Board of Education of Maizuru City and Japan Maritime Self Defense Force for transportation to Kanmuri Island and to the late S. Kurimoto for his logistic support on Mikura Island. We thank Y. Hanazaki, Y. Fujita, J. Ueda and D. Ochi for helpful assistance during our fieldwork, and members of the Kyoto University Wildlife Research Association, who assisted in our fieldwork on Kanmuri Island. We 
H. ARIMA et al.

thank N. Ohnishi for valuable comments on laboratory work. We wish to thank two anonymous reviewers and M. Brazil for their instructive comments on the manuscript. This study was partly financed by a Grant-in-Aid for Scientific Research from the Ministry of Education, Culture, Sports, Science and Technology of Japan to N. Oka in YIO.

\section{REFERENCES}

Arima H \& Ohnishi N (2006) Usefulness of avian buccal cells for molecular sexing. Ornithol Sci 5: 139-143.

Arima H \& Sugawa H (2004) Correlation between the pitch of calls and external measurements of Streaked Shearwater Calonectris leucomelas breeding on Kanmuri Island. Jpn J Ornithol 53: 40-44 (in Japanese with English summary).

Baba Y, Fujimaki Y, Yoshii R \& Koike H (2001) Genetic variability in the mitochondrial control region of the Japanese rock ptarmigan Lagopus mutus japonicus. Jpn J Ornithol 50: 53-64.

Bretagnolle V \& Lequette B (1990) Structural variation in the call of the Cory's Shearwater (Calonectris diomedea, Aves Procellariidae). Ethology 85: 313-323.

Brooke M (2004) Albatrosses and petrels across the world. Oxford University Press, New York.

Brooke MDL (1978) Sexual differences in the voice and individual vocal recognition in the Manx Shearwaters (Puffinus puffinus). Anim Behav 26: 622-629.

Brooke MDL (1986) The vocal systems of two nocturnal petrels, the White-chinned Procellaria aequinoctialis and the Grey P. cinerea. Ibis 128: 502-512.

Carey M (2011) Sexual size dimorphism within-pair comparisons and assortative mating in the short-tailed shearwater (Puffinus tenuirostris). Notornis 58: 8-16.

Cure C, Aubin T \& Mathevon N (2009) Acoustic convergence and divergence in two sympatric burrowing nocturnal seabirds. Biol J Linnean Soc 96: 115-134.

Dawson DA, Darby S, Hunter FM, Krupa AP, Jones IL \& Burke T (2001) A critique of CHD-based molecular sexing protocols illustrated by a Z-chromosome polymorphism detected in auklets. Mol Ecol Notes 1: 201-204.

Dubiec A \& Zagalska-Neubauer M. (2006) Molecular techniques for sex identification in birds. Biol Lett 43: 2-12.

Fletcher NH (2004) A simple frequency-scaling rule for animal communication. J Acoust Soc Am 115: 2334-2338.

Fridolfsson AK \& Ellegren H (1999) A simple and universal method for molecular sexing of non-ratite birds. J Avian Biol 30: 116-121.

Genovart M, Oro D, Forero MG, Igual JM, González-
Solís J \& Ruiz X (2005) Parental body condition does not correlate with offspring sex ratio in Cory's Shearwaters. Condor 107: 161-167.

Griffiths R, Double MC, Orr K \& Dawson RJG (1998) A DNA test to sex most birds. Mol Ecol 7: 10711075.

Griffiths R \& Korn RM (1997) A CHD1 gene is Z chromosome linked in the chicken Gallus domesticus. Gene 197: 225-229.

Hall TA (1999) BioEdit: a user-friendly biological sequence alignment editor and analysis program for Windows 95/98/NT. Nucl Acids Symp Ser 41: 95-98.

Jida N, Maruyama N, Oka N \& Kuroda N (1987) Structure of a colony of Streaked Shearwaters on Mikura Island. J Yamashina Inst Ornithol 19: 56-76 (in Japanese with English summary).

Kahn NW, John JS \& Quinn TW (1998) Chromosomespecific intron size differences in the avian CHD gene provide an efficient method for sex identification in birds. Auk 115: 1074-1078.

Kalendar R, Lee D \& Schulman AH (2011) Java web tools for PCR, in silico PCR, and oligonucleotide assembly and analysis. Genomics 98: 137-144.

Kiyosu Y (1965) Nihon chourui daizukan II (The birds of Japan. Vol II). Kodansha, Tokyo (in Japanese).

Kuroda N (1956) Notes of the behavior of Streaked Shearwaters in incubation period on Sangan Island. Yacho 21: 19-22 (in Japanese).

Maesako Y (1991) Effect of Streaked shearwater Calonectris leucomelas on species commposition of Persea thunbergii Forest on Kanmurijima Island, Kyoto Prefecture, Japan. Ecol Res 6: 371-378.

Maniatis T, Fritsch EF \& Sambrook J (1982) Molecular cloning, a laboratory manual. Cold Spring Harbor Laboratory Press, New York.

McNeil R, Drapeau P \& Pierotti R (1993) Nocturnality in colonial waterbirds: occurrence special adaptations, and suspected benefits. In: Power DM (ed) Current Ornithology, Vol 10. pp 187-246. Plenum Press, New York.

Ochi D, Oka N \& Watanuki Y (2010) Foraging trip decisions by the streaked shearwater Calonectris leucomelas depend on both parental and chick state. J Ethol 28: 313-321.

Oka N (2004) The distribution of Streaked Shearwater colonies, with special attention to population size, area of sea where located and surface water temperature. J Yamashina Inst Ornithol 35: 164-188 (in Japanese with English summary).

Oka N, Suginome H, Maruyama N \& Jida N (2002) Chick growth and fledgling performance of Streaked Shearwaters Calonectris leucomelas on Mikura Island for two breeding seasons. J Yamashina Inst Ornithol 
34: $39-59$.

Reis EC, Aires RM, Moura JF, Matias CAR, Tavares M, Ott PH, Siciliano S \& Lobo-Hajdu G (2011) Molecular sexing of unusually large numbers of Spheniscus magellanicus (Spheniscidae) washed ashore along the Brazilian coast in 2008. Genet Mol Res 10: $3731-$ 3737.

Ristow D \& Wink M (1980) Sexual dimorphism of Cory's Shearwater. Il-Merrill 21: 9-12.

Seki S (2003) Molecular sexing of individual Ryukyu Robins Erithacus komadori using buccal cells as a non-invasive source of DNA. Ornithol Sci 2: 135137.

Sugawa H \& Arima H (2002) Correlation between position of mounting behavior and vocalization pitch of calls in Streaked Shearwater Calonectris leucomelas. Bull JBBA 16: 43-46 (in Japanese with English summary).

Takahashi A, Ochi D, Watanuki Y, Deguchi T, Oka N, Afanasyev V, Fox JW \& Trathan PN (2008) Postbreeding movement and activities of two Streaked Shearwaters in the North-western Pacific. Ornithol
Sci 7: 29-35.

Wallschläger D (1980) Correlation of song frequency and body weight in passerine birds. Experientia 36: 69-94.

Warham J (1996) The behaviour, population biology and physiology of the petrels. Academic Press, London.

Welty JC \& Gaptista L (1988) The Life of Birds, Fourth Edition. Saunders College Publishing, New York.

Yamamoto T, Takahashi A, Oka N, Iida T, Katsumata N, Sato K \& Trathan PN (2011) Foraging areas of streaked shearwaters in relation to seasonal changes in the marine environment of Northwestern Pacific: Inter-colony and sexual differences. Mar Ecol Prog Ser 424: 191-204.

Yamamoto T, Takahashi A, Oka N, Shirai M, Yamamoto M, Katsumata N, Sato K, Watanabe S \& Trathan PN (2012) Inter-colony differences in the incubation pattern of streaked shearwaters in relation to the local marine environment. Waterbirds 35: 248-259.

Yoshida N (1962) Breeding ecology of the Streaked Shearwater at Kanmurijima Is., Maizuru in Kyoto. Tori 17: 83-108 (in Japanese with English summary). 